\title{
KARAKTERISTIK ORGANOLEPTIK DAN KIMIA PRODUK EMPEK-EMPEK IKAN CAKALANG
}

\author{
Ahmad Talib*, Marlena T* \\ *Staf Pengajar FAPERTA UMMU-Ternate, e-mail: madoks75@yahoo.co.id \\ **Alumni FAPERTA UMMU-Ternate, e-mail : -
}

\begin{abstract}
ABSTRAK
Empek-empek merupakan salah satu produk tradisional khas palembang yang terbuat dari daging lumat dan dicampurkan dengan tepung tapioka dan tepung maizena yang sanggat disukai masyarakat karena memiliki citarasa khas, enak, kenyal dan memiliki kandungan gizi yang cukup tinggi seperti protein, lemak vitamin mineral dan karbohidrat. Tujuan dari penelitian ini adalah melakukan karakteristik organoleptik dan kimia empek-empek ikan cakalang dengan konsentrasi ikan yang berbeda. Hasilnya semakin tinggi penambahan daging ikan cakalang dapat meningkatkan nilai organolpetik terhadap parameter (penampakan, bau, rasa dan tekstur) sedangkan untuk karakteristik kimia dengan penambahan daging ikan $70 \%$ dapat meningkatkan nilai kadar (air, abu, protein, lemak dan karbohidrat).
\end{abstract}

Kata Kunci: Empek-Empek, Ikan Cakalang, Kakateristik Fisiko-Kimia

\section{PENDAHULUAN}

1.1. Latar Belakang

Ikan cakalang merupakan komoditas perikanan nilai ekonomi penting karena permintaan untuk ekspor terus meningkat namun ikan cakalang juga dapat dimanfaatkan untuk pengolahan berbagai aneka produk. Produk olahan berbahan dasar ikan cakalang yang biasa dibuat secara tradisonal adalah ikan asin, ikan asap, produk fermentasi dan produk berbasis surimi. Surimi merupakan daging lumat yang dibersihkan dan dicuci berulang-ulang sehingga sebagian besar komponen bau dan lemaknya berkurang. Salah satu produk turunan surimi yang sering dibuat adalah bakso, sosis, kamaboko, nugget dan empek-empek (Anonim, 2009).

Empek-empek merupakan salah satu produk tradisional khas palembang yang terbuat dari daging lumat dan dicampurkan dengan tepung tapioka dan tepung maizena yang sanggat disukai masyarakat karena memiliki citarasa khas, enak, kenyal dan memiliki kandungan gizi yang cukup tinggi seperti protein, lemak dan karbohidrat (Anonim, 2006).

Pengolahan empek-empek dengan cara tradisonal relatif sederhana dan mudah diterapkan secara turun-temurun, proses pengolahannya dilakukan berdasarkan kebiasaan masyarakat setempat, tidak membutuhkan biaya yang tinggi (mahal), dengan menghasilkan produk yang dapat diterima oleh masyarakat.

Proses pengolahan empek-empek di Kota Palembang dilakukan dan dipasarkan secara lokal. Segera setelah ikan didatangkan ketempat pengolahan, ikan langsung ditangani dengan cara penyiangan (pembuangan kepala dan isi perut). Selanjutnya dicuci dengan air sampai bersih. Daging yang didapatkan kemudian dipisahkan dari kulit dan tulang dengan cara disayat memanjang dengan pisau pada bagian punggung sehingga diperoleh bentuk fillet ikan. Daging yang telah dipisahkan dari tulang dan kulit, kemudian digiling sampai halus (daging lumat), selanjutnya ditambahkan bumbu-bumbu, campuran maizena dan tapioka sedikit demi 
sedikit diaduk sampai homogen. Adonan yang terbentuk kemudian direbus selama 25 menit sampai matang. Empek-empek yang dihasilkan dapat dimakan dengan penambahan kuah cuka yang dibuat dari perebusan air gula merah dan cuka serta cabe rawit. Daya tahan empek-empek dapat mencapai 2 (dua) bulan, dimana produk belum menunjukkan penyimpanan/kerusakan dari sisi organoleptik seperti penampakan, bau, rasa dan tekstur sehingga masih diterima oleh masyarakat.

Sebagai upaya meningkatkan mutu sekaligus menyediakan makanan yang berbasis ikan dan produk olahannya yang aman dan bergizi, perlu dilakukan suatu upaya perbaikan dalam menghasilkan produk yang aman untuk dikonsumsi. Terbatasnya informasi tentang kandungan gizi atau mutu yang ada pada produk empek-empek dalam proses pengolahannya di Kota Ternate, menjadikan alasan pentingnya dilakukan penilitian ini. Pada penelitian ini dianalisis pengaruh penambahan daging ikan cakalang (K.pelamis) dengan konsentrasi yang berbeda terhadap mutu empek-empek, termasuk di dalamnya adalah karakteristik organoleptik dan kimia.

\subsection{Tujuan dan Manfaat Penelitian}

Penelitian ini bertujuan untuk membuat empek-empek ikan cakalang serta mempelajari pengaruh penambahan daging ikan cakalang (K.pelamis) dengan konsentrasi yang berbedabeda sedangkan manfaat dari penelitian ini diharapkan dapat memberikan informasi ilmiah kepada para pengolah tradisional di Kota Ternate tentang mutu empek-empek selama proses pengolahan dan penambahan daging ikan cakalang dengan konsentrasi yang berbeda-beda

\section{METODE PENELITTIAN}

\subsection{Waktu dan Tempat}

Penelitian ini dilaksanakan selama 2 (dua) bulan sejak bulan Mei sampai dengan Juli 2010, bertempat di Laboratorium Teknologi Hasil Perikanan (THP) Universitas Muhammadiyah Maluku Utara (UMMU) Ternate untuk uji organoleptik dan analisis kimia dilakukan di Insitut Pertanian Bogor (IPB).

\subsection{Alat dan Bahan}

Alat yang digunakan dalam penelitian ini adalah timbangan, dandang pengukus, blender, pisau, baskom plastik, erlenmeyer, homogenizer, gelas ukur, gelas piala, labu Soxhlet, labu Kjedahl, cawan porselin, kertas saring Whatman No. 45, destilasi protein, tanur, kondensor, kompor dan lembaran scoresheet serta piring untuk menyajikan empek-empek.

Bahan baku yang digunakan pada penelitian ini adalah daging ikan cakalang ( $K$. pelamis) yang diperoleh dari pasar Terminal Ternate. Bahan pembantu yang digunakan adalah garam beryodium, tepung maizena, tepung tapioka, bawang putih, bawang merah, , cuka, gula merah dan cabe rawit. Bahan kimia yang digunakan meliputi, $\mathrm{NaOH}, \mathrm{Na}_{2} \mathrm{~S}_{2} \mathrm{O}_{3}, \mathrm{NaSO}_{4}$, $\mathrm{CuSO}_{4}, \mathrm{~K}_{2} \mathrm{SO}_{4}, \mathrm{H}_{3} \mathrm{BO}_{3}, \mathrm{H}_{2} \mathrm{SO}_{4}$ dan HCL 0,1 N.

\subsection{Prosedur Penelitian}

Penelitian ini dilakukan dalam 2 (dua) tahapan, yaitu tahapan persiapan bahan baku (sampel) dan tahapan pembuatan empek-empek ikan cakalang (K. pelamis). Ikan yang baru didatangkan dari lokasi pengambilan sampel selanjutnya dilakukan penanganan dengan cara penyiangan (pembuangan isi kepala, sirip dan isi perut), lalu dicuci dengan air bersih. Ikan selanjutnya di fillet dengan cara dipisahkan antara kulit dan daging.

\subsubsection{Tahapan pembuatan empek-empek ikan cakalang \\ Daging yang telah dipisahkan dari kulit} dan tulang, selanjutnya digiling sampai halus untuk mendapatkan daging lumat. Daging yang sudah lumat kemudian ditambahkan bumbubumbu campuran (garam, sedikit gula), tepung terigu dan tepung maizena sedikit demi sedikit sambil diaduk hingga merata (homogen). Adonan yang terbentuk selanjutnya dibentuk silinder dengan diameter 2-3 cm dan panjangnya $6 \mathrm{~cm}$, kemudian direbus selama 25 menit sampai matang. Empek-empek yang telah matang kemudian didinginkan dan siap dikonsumsi dengan penambahan kuah cuka yang dibuat dari rebusan air gula merah dan cuka serta cabe rawit. Tahapan persiapan bahan baku (sampel), pembuatan dan pengujian empek-empek ikan 
cakalang (K.pelamis) dapat dilihat pada Gambar 1.

\subsection{Rancangan Percobaan dan Analisis Data}

Rancangan percobaan yang digunakan dalam penelitian ini adalah Rancangan Acak Lengkap (RAL) faktor tunggal (penambahan daging ikan) yang terdiri atas 3 taraf yaitu A0 (0 $\%)$, A1 (50 \%), A2 (70 \%) dan A3 (90\%). Masingmasing perlakuan diulang sebanyak 3 (tiga) kali. Model rancangan tersebut adalah sebagai berikut (Steel dan Torrie, 1993):

$$
Y_{i j}=\mu+\alpha_{i}+\dot{\varepsilon}_{i j}
$$

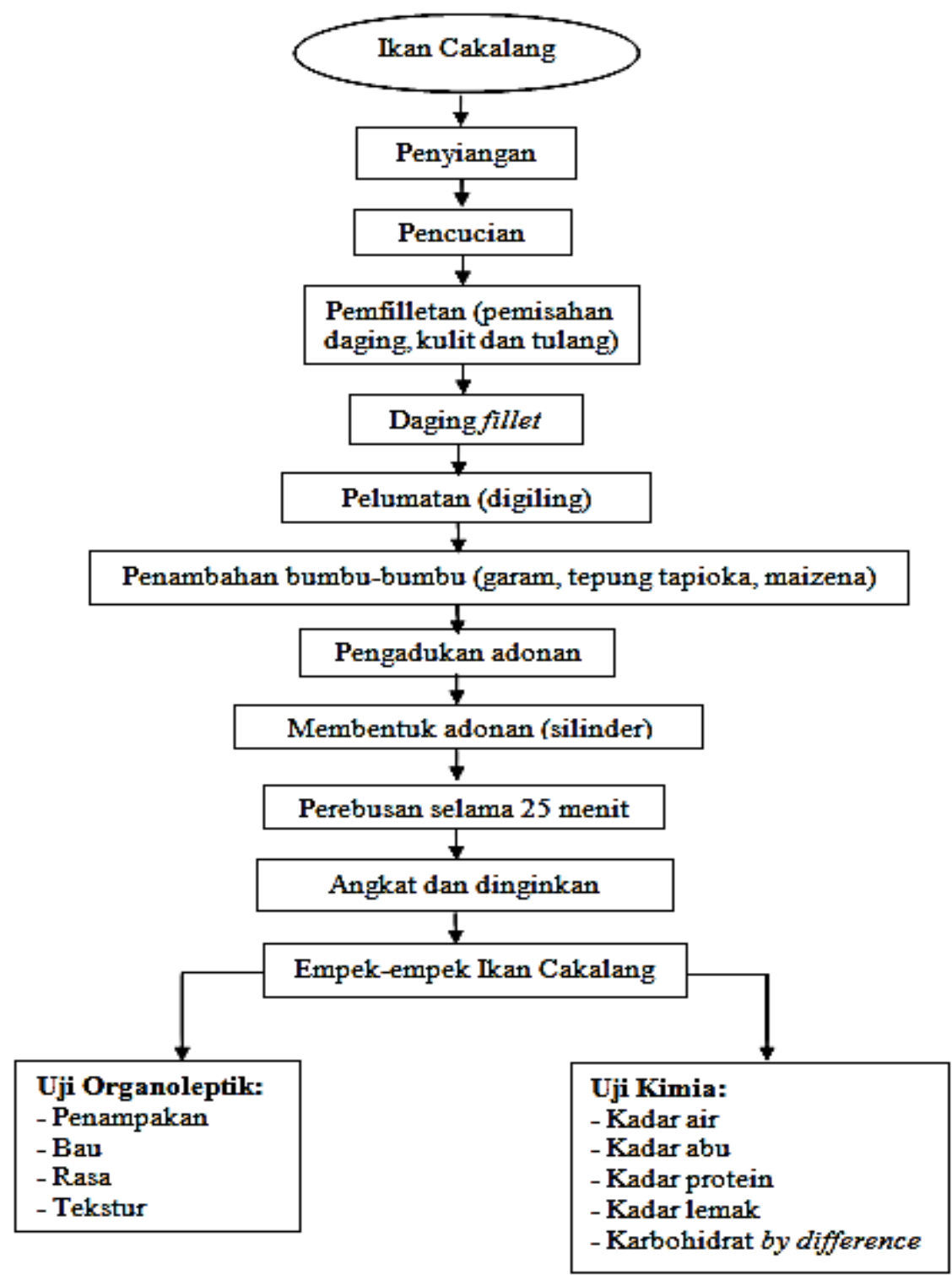

Gambar 1. Tahapan Persiapan Bahan Baku, Pembuatan Dan Pengujian Empek-Empek Ikan Cakalang
Dimana:

$\mathrm{Y}_{\mathrm{ij}}=$ Respon percobaan karena pengaruh perlakuan A taraf ke-i ulangan ke-j

$\mu=$ Nilai tengah umum atau rataan

$\alpha=$ Pengaruh penambahan daging ikan cakalang faktor A taraf ke-i (i=0, 50,70, 90)

$\varepsilon_{i j}=$ Galat percobaan

Data hasil pengamatan diolah menggunakan analisis ragam (anova) dan jika hasil menunjukkan berbeda nyata, maka dilanjutkan dengan uji Beda Nyata Terkecil (BNT) pada taraf $\alpha 0,05$ dan $0,01 \%$.
Uji Kimia:

- Kadar protein

- Kadar lemak

Karbohidrat by difference

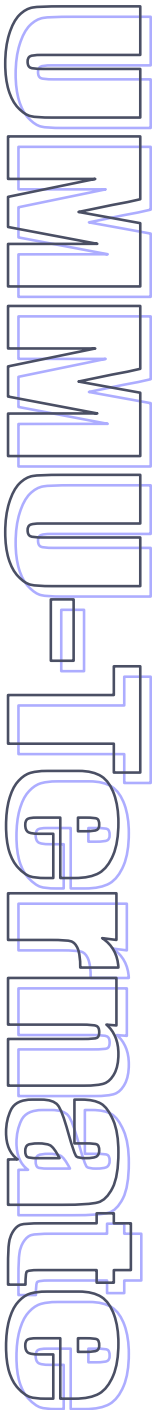


3.1. Karakteristik Organoleptik Empek-empek Ikan Cakalang

Menurut Rahayu (1998) bahwah tujuan dari pengujian organoleptik adalah untuk mengenal sifat-sifat secara objektif dari beberapa produk dan melatih panca indera untuk mengenal jenisjenis rangsangan. Karasteristik organoleptik dan bentuk empek-empek ikan cakalang yang dihasilkan dapat dilihat pada Tabel 1.

\subsubsection{Penampakan}

Penampakan merupakan karasteristik pertama yang dilihat, dinilai, disukai oleh konsumen dalam memilih atau mengkonsumsi suatu produk (Winarno, 1995). Hasil uji penilaian organoleptik terhadap penampakan empekempek ikan cakalang berkisar antara 4,84 sampai 7, 84 (kurang enak sampai sangat lebih enak).

Nilai penampakan tertinggi diperoleh pada penambahan daging ikan $90 \%$ sebesar 7,84 yang berarti tidak berongga, warna putih susu/warna merah dan nilai terendah diperoleh pada kontrol atau tanpa penambahan daging ikan cakalang. Tabel $1 \mathrm{di}$ atas terlihat bahwa terjadi peningkatan pada penambahan daging $50 \%$ dengan nilai 7,37 , kemudian mengalami penurunan pada penambahan $70 \%$ sebesar 6,80. Peningkatan kembali terjadi pada penambahan daging $90 \%$ sebesar 7,84 .

Tabel 1. Karakteristik organoleptik empek-empek ikan cakalang

\begin{tabular}{ccccc}
\hline \multirow{2}{*}{ Penambahan daging ikan } & \multicolumn{4}{c}{ Parameter yang diamati } \\
& Penampakan & Bau & Rasa & Tekstur \\
\hline Kontrol & 4,84 & 4,36 & 5,71 & 4,84 \\
$50 \%$ & 7,37 & 6,83 & 7,65 & 7,36 \\
$70 \%$ & 6,80 & 7,00 & 7,19 & 6,80 \\
90 & 7,84 & 7,48 & 8,05 & 7,84 \\
\hline
\end{tabular}

Hasil analisis ragam menujukkan bahwa perlakuan penambahan daging ikan cakalang memberikan pengaruh nyata terhadap nilai penampakan empek-empek yang dihasilkan. Hasil uji lanjut menujukkan bahwa perlakuan kontrol (tanpa penambahan daging ikan) berbeda nyata dengan perlakuan penambahan daging ikan 50, 70, dan $90 \%$, perlakuan $50 \%$ berbeda nyata dengan perlakuan 70 dan $\mathbf{9 0} \%$.

Hal ini diduga dipengaruhi oleh tepung tapioka, garam dan daging ikan yang ditambahkan serta proses pemasakan selama pengolahan dan pembuatan empek-empek, dimana tepung yang ditambahkan berwarnah putih krem dan garam disamping sebagai pemberi citarasa, garam juga berperan sebagai pembentuk warna. Selain itu juga proses pemasakan dapat merubah warna atau penampakan produk akibat reaksi gul-gula pereduksi dan protein serta karbohidrat dari tepung. Hal ini sesuai pernyataan Ketaren (1986); de Man (1997) bahwa reaksi pencoklatan (dari krem menjadi coklat) diakibatkan oleh reaksi Maillard/pencoklatan, dimana reaksi ini akan terjadi apabila adanya reaksi antara gula-gula pereduksi seperti aldehid serta gugus amin dari molekul protein yang disebabkan karena aktivitas enzim-enzim seperti fenol oksidase. Menurut Prayitno (2003) bahwa faktor penambahan bumbu-bumbu (tepung dan garam) dapat mempengaruhi sifat fungsional seperti warna, tekstur dan kekenyalan daging ikan dan produk yang dihasilkan.

\subsubsection{Bau}

Bau makanan dapat menentukan kelezatan dari makanan itu sendiri. Bau menjadi daya tarik tersendiri dalam menentukan rasa enak dari produk makanan tersebut (Soekarto dan Hubies, 2000). Umumnya bau yang diterima oleh lidah dan otak lebih banyak merupakan campuran 4 macam bau yaitu harum, asam, tengik dan hangus (Winarno, 1997).

Rata-rata nilai bau empek-empek ikan cakalang tertinggi diperoleh pada perlakuan penambahan daging ikan $90 \%$ sebesar 7,48 yang berarti tidak amis, spesifik empek-empek sedikit berkurang, sedangkan nilai terendah diperoleh 
pada perlakuan kontrol (tanpa penambahan daging ikan) dengan nilai 4,36 yang berarti tidak amis, spesifik empek-empek berkurang. Semakin tinggi penambahan daging ikan, nilai rata-rata bau mengalami peningkatan sesuai penilaian panelis.

Hasil analisis ragam menunjukkan bahwa perlakuan penambahan daging ikan cakalang memberikan pengaruh nyata pada bau empekempek yang dihasilkan. Hasil uji lanjut menunjukkan bahwa kontrol dan semua perlakuan berbeda nyata satu dengan lainnya.

Bau tidak amis yang dihasilkan diduga bahwa selama pemasakan empek-empek menghasilkan terbentuknya senyawa-senyawa menguap/volatil dan senyawa tidak menguap/non volatil. Menurut Shahidi (1998) senyawa volatil yang berperan yaitu karbonil, sulfur, hidrokarbon dan bromfenol, sedangkan senyawa non volatil yang berperan yaitu asam amino bebas, peptida, nukleotida dan basa organik dalam bahan pangan.

Bau spesifik empek-empek (ikan) dipengaruhi oleh asam-asam amino yang ada dalam daging yang ditambahkan. Hal ini menurut Ijong dan Ohta (1995) bahwa bau khas seperti ikan disebabkan adanya aroma amoniak dan asam amino glutamat yang dikandung dalam bahan pangan.

\subsubsection{Rasa}

Penginderaan rasa terbagi menjadi 4 (empat) rasa utama yaitu manis, asin, pahit dan asam. Rasa adalah respon lidah terhadap rangsangan yang diberikan oleh suatu makanan. Konsumen dapat memutuskan menerima atau menolak produk dengan 4 rasa tersebut (Winarno, 1997; Soekarto dan Hubeis, 2000).

Hasil rata-rata panelis terhadap rasa empek-empek cakalang yang dihasilkan berkisar antara 5,71 (agak enak, rasa ikan kurang) pada perlakuan kontrol (tanpa penambahan daging ikan cakalang) sampai 9,05 (enak, rasa ikan sedikit berkurang) pada perlakuan penambahan $90 \%$.

Hasil analisis ragam (Lampiran 4a) menunjukkan bahwa dari setiap perlakuan berpengaruh nyata terhadap tingkat penilaian penalis terhadap bau empek-empek yang dihasilkan. Hasil uji lanjut BNT menunjukkan bahwa kontrol (tanpa penambahan daging ikan cakalang) berbeda nyata dengan perlakuan penambahan daging 50, 70 dan $90 \%$, perlakuan $50 \%$ berbeda nyata dengan perlakuan 70 dan 90 $\%$. Perlakuan $70 \%$ berbeda nyata dengan perlakuan $90 \%$.

Rasa enak yang dihasilkan diduga berkaitan dengan penambahan garam dalam proses pencampuran adonan empek-empek dan adanya asam amino yang dikandung dalam daging ikan cakalang dalam pembuatan empekempek serta proses pemasakan yang menghasilkan senyawa pemberi cita rasa, dimana selama pemasakan menyebabkan meresapnya garam yang berfungsi sebagai pemberi cita rasa. Menurut Rahayu et al, (1992), selain berfungsi sebagai pemberi cita rasa, garam juga berperan dalam seleksi mikroba yang dikehendaki utamanya golongan proteolitik. Pemecahan protein disebabkan oleh enzim proteolitik yang terdapat dalam jaringan otot/daging ikan itu sendiri. Hal yang sama disampaikan oleh Lechninger (1993); Rahayu dan Nasran (1998) bahwa rasa agak enak, enak dan rasa manis juga dipengaruhi oleh 2 (dua) komponen utama yaitu peptida dan asam amino yang terdapat pada otot/jaringan daging. Selain itu rasa enak dipengaruhi oleh asam amino glutamat dan aspartat.

\subsubsection{Tekstur}

Tekstur merupakan segala hal yang berhubungan dengan mekanik, rasa, sentuhan, penglihatan yang meliputi penilaian terhadap kebasahan, kering, keras, halus, kasar dan berminyak (Soekarto dan Hubeis, 2000). Faktor tekstur diantaranya adalah rabaan oleh tangan, keempukan dan mudah dikunyah (Meilgaard et al, 1999 dalam Garwan, 2009). Perlakuan penambahan daging ikan cakalang pada empekempek menunjukkan trend yang fluktuatif sesuai penilaian panelis, dimana terjadi peningkatan, penurunan dan peningkatan kembali pada nilai tekstur empek-empek ikan cakalang.

Nilai tertinggi tekstur diperoleh pada perlakuan $90 \%$ dengan nilai 7,99 (padat, kompak, 
agak kenyal), sedangkan nilai terendah diperoleh pada kontrol (tanpa penambahan daging ikan) dengan nilai 6,13 (agak padat, agak kompak, kurang kenyal). Hal ini diduga bahwa pada kontrol, tidak ditambahkan daging sehingga teksturnya kurang kenyal. Tekstur agak padat dan agak kompak diduga juga berkaitan dengan bumbu-bumbu dan bahan pengisi seperti tepung tapioka dan tepung maizena yang ditambahkan selama pembuatan empek-empek ikan cakalang.

Hasil analisis ragam menunjukkan bahwa perlakuan penambahan daging ikan cakalang memberikan pengaruh nyata terhadap nilai tekstur empek-empek yang dihasilkan. Hasil uji lanjut menunjukkan bahwa kontrol (tanpa penambahan daging ikan cakalang) berbeda nyata dengan perlakuan penambahan daging 50 , 70 dan $90 \%$, perlakuan penambahan daging $50 \%$ berbeda nyata dengan perlakuan penambahan daging 70 dan $90 \%$, demikian halnya perlakuan $70 \%$ berbeda nyata dengan perlakuan $90 \%$.

Secara umum hasil yang didapatkan menunjukkan tekstur yang padat agak kenyal. Padat, kompak, agak kompak dan kenyal/kurang kenyal diduga disebabkan oleh kandungan protein yang dikandung dalam daging ikan yang ditambahkan sehinga gel yang terbentuk lebih banyak dan tekstur menjadi kenyal.

Menurut Zayas (1997), pembentukan gel tergantung pembentukan jaringan tiga dimensi otot hasil interaksi protein-protein dan proteinair yang merubah suatu struktur yang kaku. Pembentukan gel merupakan hasil ikatan hidrogen, interaksi ionik dan hidrofobik, gaya van der waals dan ikatan kovalen disulfida. Ikatan silang yang terbentuk merupakan faktor penentu pembuatan gel, semakin meningkat jumlah gel yang terbentuk, semakin meningkat kekenyalan tekstur yang terbentuk. Ditambahkan bahwa kapasitas protein daging dalam membentuk gel selama proses pengolahan produk daging merupakan sifat fungsional penting yang berperan dalam sifat tekstur dan struktur.

Diduga pula kepadatan/kekerasan dan kekompakan empek-empek disebabkan terdenaturasinya protein kolagen daging ikan cakalang yang ditambahkan pada saat pemasakan, sehingga pembentukan gel dan ikatan silang yang terbentuk lebih banyak dan tekstur lebih padat dan kompak. Hal ini menurut Bailey dan Light (1989) dalam Syartiwidya (2003) bahwa protein kologen akan terdenaturasi dan mengkerut oleh panas pada suhu sekitar $65{ }^{\circ} \mathrm{C}$ dan membentuk gel.

Empek-empek ikan cakalang dengan tekstur yang kompak diduga juga oleh protein didalam daging yang ditambahkan mengalami denaturasi pada saat pemasakan. Hal ini sesuai pernyataan Ellinger (1972) dalam Syartiwidya (2003) bahwa semakin banyak partikel protein terlarut (aktin, miosin dan aktomiosin), maka akan saling berikatan diantara partikel tersebut sehingga membentuk suatu adonan yang kompak.

\subsection{Karakteristik Kimia Empek-empek Ikan} Cakalang

Analisis kimia yang dilakukan terhadap mutu empek-empek ikan cakalang yang dihasilkan meliputi kadar air, kadar abu, kadar protein, kadar lemak dan karbohidrat by difference. Hasil uji organoleptik yang didapatkan pada empek-empek akan dilanjutkan ke uji kimia. Hasil analisis menunjukkan bahwa ke-4 (empat) perlakuan penambahan daging ikan, ternyata perlakuan penambahan daging $\mathbf{5 0}$ dan $\mathbf{7 0}$ $\%$ yang memberikan hasil terbaik (terpilih). Karakteristik kimia empek-empek ikan cakalang pada perlakuan terpilih dapat dilihat pada Tabel 2.

\subsubsection{Kadar air}

Kadar air sangat perpengaruh terhadap mutu bahan pangan, karena keawetan bahan pangan erat hubungannya dengan kadar air yang dikandungnya. Kadar air bahan pangan juga berperan dalam menentukan kemampuan mikroba untuk tumbuh dan berkembang (Winarno et al, 1993).

Perlakuan penambahan daging ikan $70 \%$ memiliki kadar air yang lebih tinggi yaitu 15,26 $\%$ dibandingkan dengan perlakuan penambahan daging $50 \%$ yaitu 15,21 \%. Rendahnya kadar air pada penambahan daging $50 \%$ diduga karena pengaruh penambahan bumbu-bumbu berupa garam yang berdifusi ke dalam daging ikan lebih 
cepat karena daging yang ditambahkan lebih sedikit sehingga jumlah kadar airnya lebih rendah.

Menurut Rahayu et al, (1992), garam merupakan elektrolit yang memiliki tekanan osmotik yang tinggi masuk ke jaringan sel dan mengakibatkan pertambahan komponen jaringan dimana garam dapat menarik air keluar dari jaringan tersebut sehingga sel akan kehilangan air dan mengalami penurunan. Ijong dan Ohta (1995) menambahkan bahwa penambahan garam kristal akan menurunkan kadar air dengan pesat dalam periode waktu tertentu. Garam yang masuk ke dalam jaringan akan menggantikan air bebas yang ada dalam daging atau otot ikan. Garam juga dapat mengawetkan ikan dengan cara mengeluarkan air dari tubuh ikan.

Perbedaan nilai kadar air pada perlakuan penambahan daging ikan 50 dan $70 \%$ pada empek-empek ikan cakalang yang dihasilkan disebabkan juga oleh cara penanganan. Menurut Winarno (1997) bahwa kadar air suatu bahan pangan dipengaruhi oleh jenis, asal, iklim dan cara penanganan bahan baku.

Tabel 2. Karakteristik kimia empek-empek ikan cakalang

\begin{tabular}{lcc}
\hline \multirow{2}{*}{ Parameter yang di amati } & \multicolumn{2}{c}{ Penambahan daging ikan cakalang } \\
\cline { 2 - 3 } & $\mathbf{5 0 \%}$ & $\mathbf{7 0 \%}$ \\
\hline Kadar air (\%) & 15,21 & 15,26 \\
Kadar abu (\%) & 10,52 & 10,71 \\
Kadar protein (\%) & 10,29 & 10,92 \\
Kadar lemak (\%) & 79,93 & 80,98 \\
Karbohidrat by difference (\%) & 15,58 & 14,64 \\
\hline
\end{tabular}

\subsubsection{Kadar abu}

Kadar abu merupakan salah satu komponen dalam bahan makanan. Komponen ini terdiri dari mineral-mineral seperti kalsium, fosfor, natrium dan tembaga (Winarno, 1995). Nilai rata-rata nilai kadar abu pada perlakuan penambahan daging ikan sebesar $70 \%$ lebih tinggi yaitu 10,71 \% dibandingkan dengan perlakuan penambahan danging ikan $50 \%$ yaitu $10,52 \%$. Tinggi rendahnya nilai kadar abu diduga pengaruh penanganan yang tidak sempurna sehingga kandungan-kandungan mineral yang masih ada pada daging ikut terbawa selama proses pembuatan empek-empek. Selain itu juga penambahan garam sebagai bahan tambahan selama pembuatan adonan empek-empek ikan cakalang dapat mempengaruhi kadar abu yang ada dalam bahan, dimana garam yang digunakan adalah garam yodium yang mengandung beberapa mineral. Hal ini sesuai pernyataan Anonim (2005) bahwa garam yodium adalah garam mineral yang mengandung zat/iodium dan klorida yang biasanya terdapat pada garam dapur yang tersedia bebas di pasaran. Garam tersebut dapat meningkatkan kadar abu dalam jumlah tertentu. Ditambahkan Winarno (1995) bahwa cara penanganan yang kurang sempurna dapat menyebabkan hilang bahkan meningkatnya kandungan mineral (abu) dalam bahan pangan.

\subsubsection{Kadar protein}

Protein merupakan suatu zat makanan yang paling penting bagi tubuh karena berfungsi sebagai zat pengatur dan pembangun, selain itu protein juga berfungsi sebagai bahan bakar dalam tubuh (Winarno et al, 1993).

Pengaruh penambahan daging ikan cakalang menunjukkan bahwa nilai kadar protein tertinggi diperoleh pada perlakuan penambahan daging ikan $70 \%$ dengan nilai 10,92 $\%$ dan nilai kadar protein terendah diperoleh pada perlakuan penambahan daging ikan $50 \%$ dengan nilai $10,29 \%$.

Tinggi rendahnya kadar protein diduga oleh jumlah/konsentrasi daging dan garam yang ditambahkan pada proses pembuatan empekempek. Kadar protein erat hubungannya dengan kandungan air. Hal ini diuraikan oleh Rahayu et al, (1992); Winarno et al, (1993) bahwa segera setelah terjadi penarikan air, protein dalam jaringan daging ikan akan terlepas dan larut 
dalam larutan. Selama penambahan garam, maka sifat garam akan mengabsorbsi air dan protein dari jaringan daging sehingga protein dalam bentuk makromolekul akan terurai menjadi derivatnya seperti peptida, asam amino dan komponen lainnya yang mempunyai berat molekul rendah.

Tinggi rendahnya kadar protein pada empek-empek ikan cakalang yang dihasilkan disebabkan juga oleh pemecahan protein oleh enzim-enzim yang ada dalam daging ikan pada saat pemasakan (pengukusan). Hal ini menurut Kimura et al, (2001); Lopetcharat et el, (2001) dalam Garwan (2009), bahwa pemasakan (pengukusan, perebusan dan pemanggangan) serta penyimpanan dapat menyebabkan protein, peptida dan asam amino terurai menjadi komponen lebih sederhana yang mempunyai berat molekul rendah dan berkontribusi terhadap nilai flavor (rasa dan aroma). Lebih lanjut ditambahkan oleh Lenah (1993), protein daging ikan akan terpecah menjadi miogen, miosin, aktomiosin, peptida dan asam-asam amino pada saat pemasakan.

\subsubsection{Kadar lemak}

Soediaoetomo (2004), lemak adalah sekelompok ikatan organik yang terdiri atas unsur-unsur carbon $(\mathrm{C})$ hidrogen $(\mathrm{H})$ dan oksigen (O) yang mempunyai sifat dapat larut dalam zatzat pelarut tertentu (petroleum, benzene dan ether). Lemak sebagai bahan atau sumber pembentuk energi dan merupakan bahan penghasil energi yang terbesar dibandingkan unsur gizi lainnya (Adawyah, 2006). Hasil analisis rata-rata nilai kadar lemak empek-empek ikan cakalang.

Pengaruh penambahan daging ikan cakalang terhadap kadar lemak empek-empek ikan cakalang yang dihasilkan menunjukkan bahwa rata-rata nilai kadar lemak tertinggi diperoleh pada perlakuan penambahan daging ikan $70 \%$ yaitu $80,98 \%$, sedangkan $79,93 \%$ adalah nilai terendah yang diperoleh pada perlakuan penambahan daging ikan $50 \%$.

Tinggi rendahnya kadar lemak pada empek-empek ikan cakalang yang dihasilkan diduga akibat pengaruh pemasakan/pemanasan (pengukusan) adonan dan aktivitas enzim pada proses pembuatan empek-empek. Hal ini menurut Buckle et al, (1987) bahwa pengolahan dengan panas mengakibatkan hilang atau meningkatnya beberapa zat gizi terutama zat-zat yang labil seperti lipida. Selain itu enzim lipase yang ada pada daging ikan dapat menyebabkan terjadinya oksidasi lemak dan hidrolisa lipida sehingga dapat meningkatkan asam lemak bebas.

Tinggi rendahnya kadar lemak bisa diakibatkan juga oleh kontaminasi silang antara udara dan bahan pangan lain yang disimpan dalam wadah yang sama. Hal ini sesuai uraian Buckle et al, (1987) bahwa lemak dapat mengabsorpsi zat menguap yang dihasilkan dari bahan lain sebagai contoh pencemaran bau dalam sayuran, buah, telur dan lemak daging yang disimpan dalam ruangan yang sama.

\subsubsection{Karbohidrat by difference}

Almatsier (2004), fungsi utama karbohidrat adalah menyediakan energi pada tubuh manusia. Karbohidrat yang terdapat dalam makanan umumnya berasal dari tumbuh-tumbuhan dan hanya sedikit saja dalam makanan hewan. Karbohidrat terdapat dalam jumlah yang sangat kecil pada tubuh ikan, diantaranya berupa polisakarida dan glikogen (Winarno 1992; Poernomo 2002).

Perlakuan penambahan daging ikan $50 \%$ yaitu $15,58 \%$, sedangkan nilai terendah diperoleh pada perlakuan penambahan daging $70 \%$ yaitu $14,64 \%$. Tinggi rendahnya nilai karbohidrat by difference diduga oleh penguraian pati yang dikandung tepung maizena dan tepung tapioka yang ditambahkan selama pembutan empekempek. Hal ini sesuai uraian Buckle et al, (1987) bahwa perubahan biokimia dapat terjadi pada komponen karbohidrat tepung seperti terjadinya hidrolisis pati karena kegiatan enzim amilase, terbentuknya bau asam dan bau apek dari karbohidrat akibat aktivitas mikroorganisme dan reaksi pencoklatan non-enzimatis.

Perbedaan nilai rata-rata karbohidrat by difference pada empek-emepek ikan cakalang bisa diakibatkan juga oleh pengaruh pemasakan (pengukusan) adonan (tepung, daging ikan dan bumbu-bumbu tambahan lainnya). Hal ini menurut Buckle et al, (1987) bahwa pengolahan dengan panas mengakibatkan hilang atau 
meningkatnya beberapa zat gizi terutama zat-zat yang labil.

\section{PENUTUP}

4. 1. Kesimpulan

1). Hasil penelitian menunjukkan bahwa semakin tinggi penambahan daging ikan cakalang pada produk empek-empek maka nilai organoleptik juga ikut meningkat.

2) Hasil analisis kimia menunjukkan bahwa penambahan daging ikan cakalang $70 \%$ dapat meningkatkan nilai (kadar air, proetein, lemak dan kabohidrat) sedangkan dengan penambahan daging ikan $50 \%$ justru kadar tersebut menurun.

\subsection{Saran}

Perlu dilakukan penelitian lanjutan tentang pembutan empek-empek dengan menggunakan jenis ikan berbeda dan dilanjutkan dengan uji mikrobiologi.

\section{DAFTAR PUSTAKA}

Adawyah R. 2007. Pengolahan dan Pengawetan Ikan, Bumi Aksara, Jakarta.

Almatsier S. 2004. Prinsip Dasar Ilmu Gizi. Penerbit Gramedia Pustaka Utama Jakarta.

Anonim. 2006. Pengolahan Ikan dan Hasil Laut. Badan Riset Kelautan dan Perikanan. Departemen Kelautan dan Perikanan, Jakarta.

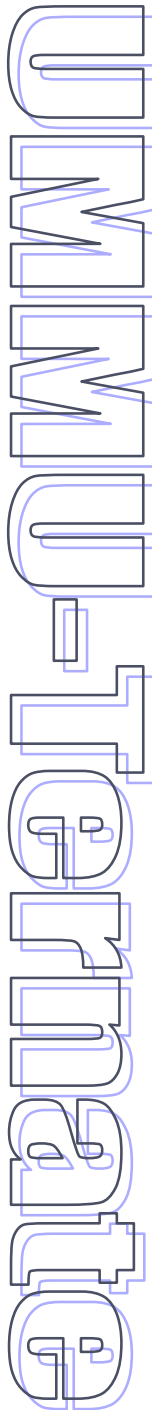
2009. Pengetahuan Umum Usaha Sektor Kelautan.www.google.com [Diakses Oktober 2010].

[AOAC] Association of Official Analytical Chemist. 1995. Official Methods of Analysis. Washingthon DC.

Buckle KA. Edwards RA, Fleet GH, Wooton M. 1978. Ilmu Pangan. Penerjemah: Hari Purnomo dan Adiono.Penerbit PT. Universitas Indonesia Press (UIP).

de Man JM. 1997. Priciples of Food Chemistry. Edisi kedua. Penerjemah: Padmawinata K. Bandung: Penerbit Institut Teknologi Bandung.

Garwan R. 2009. Perkembangan histamin selama proses fermentasi dan penyimpanan produk bakasang jeroan ikan cakalang (Katsuwonus pelamis, L) [tesis]. Bogor. Program pascasarjana, Departemen Teknologi Hasil Perairan, Institut Pertanian Bogor.

Ijong FG, Ohta Y. 1995. Amino acid composition of bakasang, a traditional fermented fish sauce from Indonesia. Journal of Microbiological Methods. 25: 236-237.;

Ketaren S. 1986. Pengantar Teknologi Minyak dan Lemak Pangan. Penerbit Universitas Indonesia (UI) Press, Jakarta.

Lechninger AL. 1993. Dasar-dasar Biokimia. Jilid 2. Thenawidjaja M. penerjemah. Terjemahan dari Priciples of Biochemistry. Jakarta: Penerbit Erlangga.

Lenah. 1993. Pembuatan bakso dan sosis dari bahan dasar daging ikan cucut hasil pemasakan ekstrusi serta evaluasi mutunya [skripsi]. Bogor: Jurusan Teknologi Pangan dan Gizi, Fakultas Teknologi Pertanian, Institut Pertanian Bogor.

Lopetcharat K, Choi YJ, Park JW. 2001. Fish sauce product and manufacturing. A review: Journal Food Review: 17:65-88.

Meilgaard M, Civille GV, Carr BT. 1999. Sensory Evaluation Techniques. $3^{\text {rd }}$ eds. Florida: CRC Press.

Poernomo H. 2002. Teknologi Pengolahan Ikan. Departemen Kelautan dan Perikanan Tangkap, Jakarta.

Prayitno E. 2003. Kajian proses nugget dari surimi dan ikan manyung (Arius thallasinus) dengan bahan tambahan gelatin dari kulit ikan tuna [tesis]. Bogor: Program pascasarjana, Institut Pertanian Bogor.

[SNI] Standar Nasional Indonesia. 2006. SNI 01-2346-2006. Petunjuk Pengujian Organoleptik atau Sensori. Badan Standarisasi Nasional, Jakarta. 
Shahidi F. 1998. Flavor of Meat and Meat Product. New York: Autama Press.

Soekarto ST, Hubeis M. 2000. Metodologi Penilaian Organoleptik. Petunjuk Laboratorium. Bogor: Pusat Antar Universitas Pangan dan Gizi, Program Studi Ilmu Pangan, Institut Pertanian Bogor.

Steel RGD, Torrie JH. 1993. Prinsip dan Prosedur Statistik Suatu Pendekatan Biometrik. Penerjemah: Sumantri B. Jakarta: Gramedia Pustaka Utama hlm 748.

Rahayu WP, Ma'oen S, Suliantri, Fardiaz S. 1992. Teknologi Fermentasi Produk Perikanan. Bogor: Pusat Antar Universitas Pangan dan Gizi, Institut Pertanian Bogor.

Rahayu S, Nasran. 1998. Ikan kayu (katsuobushi) sebagai penyedap masakan. Jakarta: LIPI Prosiding Widyakarya Nasional Khasiat Makanan Tradisional.

Syartiwidya. 2003. Kajian tekstur dan perubahan mikrostruktur nugget ikan selama pengolahan dan penyimpanan [tesis]. Bogor: Program pascasarjana. Institut Pertanian Bogor.

Zayas JF. 1997. Functionally of protein in Food. Springer, Germany.

Winarno FG. 1993. Kerusakan Bahan Pangan dan Cara Pengolahannya. Departemen Teknologi Pertanian. Institut Pertanian Bogor. 1997. Kimia pangan dan Gizi. Jakarta: PT. Gramedia Pustaka Utama

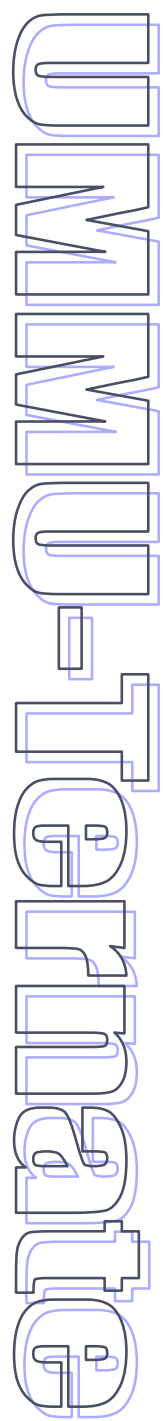

